\title{
El juicio crítico sobre la literatura latina antigua satírica en la historia literaria del XVIII
}

The critical judgement on ancient Latin satirical literature in $18^{\text {th }}$ literary history

María Asunción Sánchez Manzano

Universidad de León, IHTC

CESXVIII, núm. 30 (2020), págs. 541-565

DOI: https://doi.org/10.17811/cesxviii.30.2020.541-565

ISSN: 1131-9879

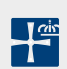

OVIEDO 


\section{Resumen}

La crítica de la literatura latina antigua comenzó a escribirse a partir de los comentarios de época imperial romana. Esta crítica antigua sirvió de pauta también para realizar una síntesis de la evolución de la literatura latina a la luz de la razón ilustrada. Sin embargo, la diversificación de los poemas humorísticos en lengua vernácula había desenfocado los rasgos auténticos de la sátira antigua, uno de los géneros literarios más característicos de Roma desde Lucilio.

Palabras clave

Sátira romana, Historia literaria, Crítica literaria.

\section{Abstract}

The critical judgement on ancient Roman literature started in early times of Empire. Those comments were collected by some scholars during the Enlightenment. It was then, when they summarized the deeds of Roman authors and their contribution to the European literature as well, under the light of reason. Labouring this synthesis, they did not confirm the ancient theory about the early beginnings of Roman satire, as a representative Latin genre since Lucilius. The humorous poems in vernacular were so diverse, that it was difficult to know the very features of this ancient Roman genre.

KeY Words

Roman ancient satire, History of Latin literature, Critics.

Recibido: 16 de enero de 2020. Aceptado: 11 de marzo de 2020. 


\section{O. La recepción humanista de la antigua sátira romana}

La historia de la literatura latina, que comenzó a configurarse a finales del s. XVII ${ }^{1}$, estaba muy condicionada por las noticias conservadas en textos y escolios antiguos, que se habían recuperado en el humanismo. La escuela de época imperial había desarrollado una autoconciencia de la cultura romana a través del cuidado en la forma de escribir en latín, una técnica del estilo literario.

En cambio, la perspectiva del siglo ilustrado era necesariamente distinta, ya que, la producción artística en lengua vulgar había evolucionado. La colección de datos que se tomaron para la redacción de estas historias deriva de las listas de un itinerario de lectura y comentario consolidado en la enseñanza de los preceptores humanistas, con la adición de algunas inscripciones. La diversidad de estilo de los textos antiguos conservados no facilitaba el estudio del concepto de sátira como género literario. Por ejemplo, la preferencia de Persio por una estructura dialogada facilitaba la valoración de su obra, pues la filosofía socrática y el diálogo habían alcanzado una gran estima en el XVII. Entonces se deseaba superar el racionalismo cartesiano para conseguir un nuevo método científico, acorde con el desarrollo de las ciencias que se había producido desde 1500.

Pierre Laurens, al revisar la tradición de la crítica, observaba un error acerca de la génesis de la sátira antigua que se había mantenido durante siglos. La filiación de la sátira romana a partir de la comedia ática antigua fue una hipótesis fundada en la interpretación de unos versos horacianos ${ }^{2}$ (sat. 1, 4,

1 Francisco García Jurado, «La efímera existencia de la Historia Latinae linguae en España: Casto González emeritense y el absolutismo ilustrado de Carlos IV», EClás 141 (2012), págs. 93-123, en págs. 96-100 explicaba una teoría del origen del concepto de «historia literaria» a través de las colecciones de bibliotecae (FABricius) y la periodización de la historia de la lengua latina (MoRHOF, FuncK, Wolf) para llegar a un estudio propiamente literario. Francisco García Jurado-Bernd Marizzi, «La primera historia de la literatura romana: el programa del curso de Friedrich August Wolf», CFC 29, 2 (2009), págs. 145-177; F. GARCíA JuRADO, «La poética frente a la historia literaria en los manuales españoles de literatura latina durante el s. XIX español. Política y humanidades», en Jesús Luque-María Dolores Rincón-Isabel Velázquez (eds.), Dulces Camenae Poética y poesía latinas, Jaén-Granada, Sociedad de Estudios Clásicos, 2010, págs. 1371-1382.

2 Hor. serm. 1, 4, 1-7 (trad. de Horacio Silvestre, Madrid, Cátedra, 1996): «Los poetas de Éupolis, Cratino y Aristófanes (citados por Qvint. inst. 10, 1, 66), / y demás varones representantes de la Comedia Antigua, / si alguien era digno de ser retratado, porque fuera malo / y ladrón, porque fuera adúltero o sicario 
1-7). Realmente tenía sentido relacionar ambos tipos de composición sabiendo que la literatura romana se había constituido importando la doctrina literaria helenística. Sin embargo, la función social de las composiciones dramáticas humorísticas de los griegos era distinta desde el origen, y no se encontraba una continuidad temática en la sátira romana. Además, los afamados humanistas Angelo Poliziano, Jules César Scaliger, Robert Estienne, Daniel Heinsius, Gerhard Johannes Vossius, Charles Batteux y los enciclopedistas franceses no dieron importancia a la diversidad de metros de la sátira respecto al pretendido origen helénico, cuya forma versificada específica no se había imitado en latín.

Aunque este era un defecto principal de la teoría humanística más difundida sobre la sátira, no empañó el atractivo de los textos antiguos. El poeta latino Lucilio, al introducir el hexámetro latino como metro de la sátira, evitó los metros de las comedias latinas, que sí podían haber heredado alguna característica del drama satírico griego ${ }^{3}$.

En cambio, Isaac Casaubon (De satyrica Graecorum poesi et Romanorum satira, París, 1605) sostuvo entre los humanistas la opinión de un origen auténticamente romano. Justo Lipsio y Nicolas Boileau-Despréaux ${ }^{4}$ prefirieron esta explicación y entendieron la sátira a través de la variedad de temas y metros de la sátira menipea. La desvergüenza de Menipo de Gádara se había transmutado en la mezcolanza elegida por Varrón para introducir el género en la literatura latina ${ }^{5}$.

Ciertamente, la diversidad de las composiciones de la sátira varroniana conectaba con formas literarias breves, muy características de la transmisión oral. Entre ellas, las formas breves más comunes en la tradición helénica mostraban

\footnotetext{
o infame por / alguna razón, lo censuraban con mucha libertad. / De aquí depende todo Lucilio, que siguió a estos, / solo que cambiando los pies y ritmos; gracioso, / de fino olfato, incansable en componer versos». Rosario Cortés Tovar, «Horacio y su historia de la sátira», CFC 37,2 (2017), págs. 239-263, al comentar ese pasaje explicó cómo Horacio tomaba distancia de la tradición helénica.

3 Rosario CORTÉs Tovar, «Horacio y su historia», pág. 243; más adelante (págs. 256-257), reconocía que Horacio señalaba a su manera los tres hitos principales del género de la sátira hasta su tiempo.

4 Pierre Laurens, Histoire critique de la littérature latine. De Virgile à Huysmans, Paris, Les Belles Lettres, 2014, págs. 303-304 y n. 2. Se puede entender la secuencia del debate por la lectura del prefacio de Thomas Crenius a una reedición del discurso de Isaac Casaubon en Halle, en 1774 (apud Gabaveri viduam et filium), págs. VIII-IX. Las ediciones de las sátiras menipeas aparecieron con regularidad desde los últimos años del s. XVI. La imitación de John BARCLAY en Euphormionis Lusinini Satyricon actualizaba los recursos de Petronio y Luciano.

5 Rosario Cortés Tovar, «Libertas en la sátira de Horacio a Juvenal», Antonio Alvar (ed.) Actas del XI Congreso Español de Estudios Clásicos, Madrid, Sociedad Española de Estudios Clásicos, vol. 2. 785-794 y «Libertad de expresión en Juvenal: Scribendi quodcumque...liberet», en Gregorio Hinojo Andrés (ed.), Munus quaesitum meritis: homenaje a Carmen Codoñer, 2007, págs. 183-191, en págs. 185-187 desarrollaba el comentario de los límites de esta expresión en la sátira romana, de acuerdo con las convenciones sociales y culturales.
} 
la permeabilidad del arte literario antiguo a la filosofía práctica. En la herencia latina, la narrativa breve del elogio, de las sentencias y ejemplos contrastaba con la sátira romana, que se relacionaba con la poesía epódica y epigramática. Si la fabulística griega unía los exempla al enthymema, la recepción romana de la filosofía cínica favoreció el enriquecimiento de la sátira autóctona. La estructura de la fábula no difería mucho de la fértil compilación temática que floreció en emblemas, empresas y argucias en Europa. Tuviera parte de versos, o en prosa (recordemos los prosímetros romanos), contenía una breve narración o descripción de una escena, seguida de un promythion, y un epimythion, para llegar finalmente a una conclusión.

Edward V. Coughling ${ }^{6}$ concluye al final de su estudio sobre la sátira algunos rasgos de la literatura satírica castellana, que facilitan la comprensión de aquella perspectiva que posiblemente tuvieran los historiadores acerca de los clásicos romanos. Por su parte, Francisco Uzcanga Meinecke ${ }^{7}$ indicaba que la sátira de tradición lucianesca «muere como género a finales del siglo XVIII» y su sustituto didáctico-satírico es la fábula.

Para aclarar todo esto, nos ocuparemos del debate sobre el origen de la sátira romana, su relación (didáctica, máscara, risa) con la sátira menipea, de la relación de la sátira romana con otras formas de literatura joco-seria en neolatín y en otras lenguas, teniendo en cuenta el concepto de género literario que definían las obras de los autores latinos. Revisaremos en adelante las opiniones de los tratados de historia de la literatura latina más antiguos, advirtiendo las diferencias de juicio entre sus autores sobre el carácter genérico de la sátira y su definición, según se fue perfilando en el XVIII y se consagró como modelo explicativo en el XIX.

6 Edward V. Coughling, La sátira del siglo XVIII. Isla, Jovellanos, Moratín y la cultura de la época ilustrada, Nueva York, Peter Lang, 2013, págs. 106-107: «La sátira difiere de la obra puramente didáctica o filosófica. Es una modalidad persuasiva en la cual una ficción que depende de la imaginación creativa está motivada por un impulso didáctico-moral. Pero, al contrario del género empírico y racionalista, la sátira responde a una estética compleja que requiere distintos elementos entre los cuales se destaca el lenguaje degradante y burlesco [...]. Lo que rige la sátira, más que un código social o moral determinado, es el deseo estético de expresarse en esa modalidad literaria».

7 Francisco Uzcanga Meinecke, Sátira en la Ilustración española. Análisis de la publicación periódica El Censor (1781-1787), Frankfurt am Main, Vervuert, 2004, pág. 17. Este investigador reconocía la trayectoria de la tradición literaria clásica: «Situaríamos a Luciano, Petronio o Séneca entre los representantes clásicos de la sátira menipea e incluiríamos también a los autores que originan un renacer de la misma, como Erasmo, Rabelais, Dryden, Swift, o Quevedo, autores que se consideraban ellos mismos dentro de la tradición menipea». Por ejemplo, Rabelais empleaba la parodia y la descripción grotesca, al modo de Luciano en su Quart libre. Beatriz Coca Méndez, «La escala de los dominios de sire Gaster: ¿̨testimonio o colofón de las fobias de Rabelais?», en Àngels SANTA y Cristina Solé CASTELls (eds.), Texto y sociedad en las letras francesas y francófonas, Lleida, Departament, 2009, págs. 71-78. 
Para uno de los primeros historiadores de la literatura latina, René Pichon, la aportación más estimable del género satírico romano es la risa ${ }^{8}$, pero en un contexto de rivalidad entre los poetas; según esta opinión, parecía el género más indicado para expresar una discrepancia crítica entre los eruditos concurrentes. En todo caso, dejaremos la sátira propiamente política de estos siglos —asunto que daría ocasión a un estudio específico- al margen de nuestra perspectiva sobre la sátira romana antigua.

Por eso, en primer lugar, trataremos de explicar el proceso de estudio de esta clase de poemas por parte de la crítica, a partir de cómo la extensión de las formas poéticas breves, didácticas o moralizantes cambiaba la percepción de la sátira antigua entre los historiadores de la literatura.

1. La extensión de las formas literarias breves: sátira, didáctica y filosofía del XVII

Muchos aspectos temáticos de estos géneros literarios reflejan con claridad las formas de pensar y sentir que identificaban a los hombres de ese siglo. Pero la ironía y la máscara ensombrecían la presencia real del crítico detrás de sus líneas y versos. Otras veces, los poetas se armaban de ella para exhibir vanidosamente sus opiniones sobre la producción poética o contrastarlas con los demás. Esa máscara, que marcaba una distancia para que la atención se centrara en una ambigüedad interpretable, fue considerada un rasgo identificativo del género.

Su carácter retórico parece evidente, no solo en el análisis de su estructura concreta, sino en el marco de los ejercicios fundados en las sentencias. En el Medioevo habían servido también de base a esas diversiones de la corte que consistían en anécdotas o fábulas de aplicación moralista; esta forma de expresión contenía avisos políticos algunas veces. La historia literaria naciente en el XVII destacaba los autores y obras más imitadas, y la sátira romana apenas resaltaba entre ellas.

La obra de Horacio había sido la inspiración principal de la actividad poética desde los primeros momentos de la renovación humanística. La norma horaciana es la norma del equilibrio, del discurso sólido sin demasiados juegos

8 René Pichon, Histoire de la littérature latine, $5^{\text {me }}$ ed. revue, Paris, Hacchette, 1912, pág. 108: «Lucilius, au contraire, est le créateur de la poésie amusante, de la vraie satire. [...] La satire est avant tout une raillerie: l'esprit latin est volontiers moqueur et bouffon. C'est aussi une oeuvre practique et polémique; Horace s'en sert contre ses envieux, Perse contre les tyrans, Juvénal contre tout le monde: ce caractère combatif va bien aux goûts belliqueux des Romains; la satire est leur genre préféré avec l'éloquence, parce que toutes deux sont encore de l'action". 
de artificio. Precisamente este autor había sido mejor considerado entonces como satírico moralista que como el poeta autor de las Odas. Sin embargo, con el paso del tiempo, su Arte poética mereció tal consideración como guía de la composición literaria que representó la faceta más brillante e ilustrativa de su creación ${ }^{9}$.

En el reinado de Luis XIII experimentó un gran auge la literatura satírica y burlesca francesa ${ }^{10}$, un fenómeno que adornó el crecimiento del espíritu crítico y facilitó la reevaluación crítica de la literatura clásica. Ciertamente en este contexto, al que los libertinos franceses añadirían después la audacia de mostrar su desacato a las virtudes morales que sostenían el Estado de entonces, se produjo una selección de la poesía antigua.

Tras la Revolución, uno de los primeros tratados de historia literaria, el de Johann Christian Felix Bähr ${ }^{11}$, esbozaba por su cuenta una teoría del origen de la sátira. Dejando a un lado la relación con el drama satírico griego, presentaba un estadio inicial de la sátira romana en los versos atrevidos que cantaban los soldados romanos a su general con ocasión de la procesión del triunfo militar, y las inscripciones satíricas en verso que la arqueología había ido coleccionando e interpretando desde finales del siglo xvi. En todo caso, la denominación que proponía para el estudio de esta clase de textos correspondía a la poesía epigramática: versus ludicri.

Por esa denominación había adquirido autoridad François Vavasseur, que dedicó su estudio sobre la risa en las literaturas antiguas a la memoria del atrevido Guez de Balzac. De acuerdo con su criterio, en Francia la exageración de la sátira fue cediendo desde 1660 aproximadamente. Por esa época, Nicolás Boileau distinguía un exceso de la capacidad crítica en la risa irónica y sarcástica de la obra de Clément Marot ${ }^{12}$. La irrupción de bromas excesivas en la literatura de la época suscitó una reacción fuerte, que trató de fijar los límites a la pretendida libertad que algunos defendían. El jesuita padre Vavasseur ha-

9 Manuel Mañas NúÑEz, Arte poética y otros textos de teoría y crítica literarias, Cáceres, Universidad de Extremadura, 2006, págs. 26-27 admiraba el relieve cultural alcanzado por esta obra horaciana.

10 Elena Russo, Styles of Enlightenment: Taste, Politics and Authorship in Eighteenth-Century France, Baltimore, The John Hopkins University, 2007, pág. 39.

11 Johann Christian Felix B̈̈нR, Manuel de l'histoire de la littèrature romaine, Louvain, Vaulinthout, 1838, recogía la evolución de esta literatura en el conjunto de los testimonios antiguos, pág. 241. En el capítulo sobre este género literario (págs. 33-37 y 123-126) advertía la necesidad de distinguir el drama satírico, y por supuesto, composiciones teatrales cuya finalidad principal era la enseñanza: «In ne faut pas confondre l'ancienne satire romaine du genre dramatique avec la satire didactique». Una traducción de 1879 al castellano de este manual ha sido citada por Francisco García JuRAdo en su Catálogo razonado de manuales hispanos de literatura clásica (CRMHLC) (1782-1935), Madrid, Guillermo Escolar, 2019, pág. 1.

12 Nicolas Bolleau-Despréaux, Art Poétique, I, 119-122: «Marot bientôt après fit fleurir les ballades / Tourna des triolets, rima des mascarades / A des refrains réglés asservit les rondeaux». 
bía estudiado el tema desde una perspectiva más amplia, analizando las obras producidas en las distintas etapas de la evolución literaria desde los clásicos griegos, las obras de Aristófanes y Jenofonte, la habilidad de Platón para referir anécdotas, sin olvidar las reservas demostradas por Cicerón y Quintiliano acerca del humor en la literatura. Pero sus observaciones fueron útiles para la historiografía literaria.

Otro tipo de obra que fue tenida en cuenta al escribir la historia fue el diccionario de autores con comentarios críticos de la producción de cada uno. Así, Thomas Pope Blount en su Censura recordaba el prestigio literario de Vavasseur en Francia:

Apud populares suos varia expertus est judicia ob novum aliquod dictionis genus in Gallico sermone. Est enim argutus, floridus, metaphoris aliquantulum indulgens; quae scribendi ratio quibusdam qui castigatiores videri volebant, displicuit. Nam Satyrae adversus illum scriptae et integri libri quos ipse tamen valide satis excepit et retudit ${ }^{13}$.

La trascendencia de la polémica que suscitó sobre el estilo literario en francés es bien conocida, pues, según este crítico: «Tanta vis est atque sublimitas, tam felix audacia, tam nihil puerile, nihil otiosum atque arcessitum» ${ }^{14}$. De este modo, la aplicación de Balzac a la composición de obras burlescas dio a Vavasseur la oportunidad de historiar el género satírico desde la Antigüedad. Por eso mereció un espléndido elogio de Pope Blount:

Citra omnem exaggerationem dici potest eum si alius quisquam hoc saeculo in tota Europa, omnes linguae Latinae modos et argutias optime calluisset, imo nonnulli profiteri non dubitarunt neminem forsan ab Augusti saeculo illum purius et elegantius esse locutum ${ }^{15}$.

13 Thomas Pope Blount, Censura celebriorum authorum sive tractatus in quo varia virorum doctorum clarissimis cujusque seculi scriptoribus iudicia traduntur, Genevae, apud Samuelem de Tournes, 1696, págs. 1031-1032: «Entre sus amigos recibió distintos juicios por el nuevo género literario en francés. Ciertamente es agudo, florido, un tanto indulgente con las metáforas; esta clase de composición no gustó a algunos que deseaban que se corrigieran, pues recibió sátiras contra él y libros enteros que refutó vigorosamente».

14 Thomas Pope Blount, Censura, pág. 1032 sobre el estilo de Guez de Balzac dice que tiene: «Tanta fuerza y excelencia, una audacia tan certera, tanta que nada pueril, que nada ocioso se añade».

15 Thomas Pope Blount, Censura, págs. 1051-1053: «Sin exagerar se puede decir que él había adquirido una competencia como nadie en este siglo en toda Europa en todos los conocimientos de lengua latina y en las argucias; es más, algunos no dudaron en reconocer que quizá nadie desde la época de Augusto ha hablado con mayor pureza y elegancia que él». 
Con un gran prestigio conseguido en el dominio del estilo en las buenas letras, Vavasseur contribuyó a tomar distancia de la tendencia satírica y burlesca francesa. Después, esta actitud se extendió sobre el resto de Europa al crecer la influencia cultural de Francia ${ }^{16}$. Así lo reconocía Pope Blount ${ }^{17}$ :

Liber ille de ludicra dictione qui joculares poetas nostros lacessit, mirificus est in suo genere, nec solidius ingeniosusque ratiocinari potest quisquam [...]. Si vero disertus Dom. Balzacius paulo diutius superstes fuisset incomparabilem illum tractatum totis viribus laudasset.

Además de las ediciones comentadas de los autores clásicos, había otro género de obras que ofrecían comentarios útiles para entender las diferencias de composición de la literatura clásica. En el XVI se había difundido desde Italia la obra de anécdotas de Paulo Manuzio, y en España fueron bien conocidas entre los jesuitas la Varia historia o Miscelanea de Luis Zapata ${ }^{18}$ y las anécdotas del Jardín de flores curiosas de Antonio de Torquemada ${ }^{19}$. A finales del XVI, la Philosophia antigua poetica de Alonso López Pinciano dedicó alguna atención a las colecciones de mirabilia. Marcial y su epigrama habían sido el modelo de emblemas y empresas que facilitó el paso a una forma de sátira joco-seria, de muy variada temática en el s. $\mathrm{XVII}^{20}$.

16 En la censura de Adrien BAILLET, Jugemens des sçavans sur les principaux ouvrages des auteurs, tome quatrième contenant les poetes, seconde partie, à Paris, chez Antoine Dezalier, 1686, págs. 276-277 encontramos unos «jugemens sur les Satyres d'Horace» en los que se alude a un juicio sobre la sátira horaciana buscando un comedimiento que el género literario romano antiguo no tenía y que Boileau trata de prestigiar: «Monsieur Despreaux semble n'avoir pas voulou exclure l'aigreur du caractere satyrique d'Horace et dire qu'il s'est contenté d'ajouter à celle de Lucillius ce qui parvoit luy manquer pour la perfectionner et pour la rendre plus agreable et plus utile».

17 Pope Blount, Censura, págs. 1052-1053. «El libro De ludicra dictione, que ataca a nuestros poetas satíricos, es maravilloso en su género y no se puede pensar nada más sólido ni más ingenioso [...] Si el erudito señor Balzac hubiera vivido un poco más de tiempo, habría elogiado encarecidamente aquel incomparable tratado».

18 Aunque explicaba el origen antiguo Irene Pajón LeYra, Entre ciencia y maravilla. El género literario de la paradoxografía griega, Zaragoza, Prensas Universitarias de Zaragoza, 2012, en especial, en págs. 168-191, pocas veces los mirabilia tienen un sentido burlesco. Este género se entiende en el contexto de la literatura oral antigua y su recepción posterior hasta el humanismo.

19 Isabel Muguruza Roca, «Los disparates de Antonio Torquemada: maravillas caballerescas y erudición miscelánea», en Natalia Fernández Rodríguez-María Fernández Ferreiro (eds.), Literatura medieval y renacentista en España: líneas y pautas, Salamanca, SEMYR, 2012, págs. 733-741, en pág. 736.

20 Como contraste para valorar la recepción de la sátira romana, Rosario CoRTÉs Tovar presentaba «Marcial en España», Humanitas 56 (2004), págs. 225-326; «Epigrama y sátira: relaciones entre la poética de Marcial y la de los satíricos», en José Javier Iso Echegoyen (ed.), Hominem pagina nostra sapit: Marcial 1900 años después, págs. 35-56, en especial pág. 51. 
Antonio Pérez Lasheras ${ }^{21}$ trataba de exponer el fenómeno literario de las agudezas del s. XVII, tanto en latín como en vulgar, recordando a Vavasseur, sin olvidar a aquellos que se habían interesado por buscar sus fuentes en la tradición clásica. Ciertamente, en estas colecciones se encuentran también recursos comunes de la sátira romana como la burla, la parodia, la ironía y lo ridículo. También Eustaquio Sánchez Salor hace tiempo que destacó estos modos de comicidad en su explicación del conceptismo español ${ }^{22}$.

Por otro lado, el uso literario de lo ridículo tenía el precedente de la polyanthea clásica, medieval y humanística. Pero la comicidad del humor refinado no necesitaba ridiculizar ni parodiar abiertamente sus objetos. Advertimos la semejanza entre los tratados de ejercicios retóricos, la crítica de costumbres, la crítica literaria, y la antigua forma del banquete filosófico, en la que fue muy ilustrativa la imitación de Erasmo a Plutarco al comienzo del humanismo. La extensión de esta clase de textos breves en neolatín durante el siglo XvII alcanzaba también las Islas Británicas y el centro de Alemania, donde había mucho interés por la enseñanza de la oratoria. Luciano y Petronio eran el modelo del texto satírico en prosa $^{23}$. Desde la obra poética de Samuel Johnson, la comicidad satírica se contagió no solo al teatro, sino, sobre todo, a la narrativa. Jonathan Swift, Laurence Sterne y Henry Fielding trasladaron muchos recursos humorísticos a sus novelas.

Por su parte, el famoso jesuita alemán Jacob Masen había desviado la tradicional enseñanza de los ejercicios oratorios en prosa hacia la preparación de temas adecuados para reuniones sociales y diplomáticas sobre pequeñas anécdotas históricas contenidas en las obras de Plutarco. En estos textos breves se recurría a una descripción o a una comparación, en ocasiones teñida con el

21 Antonio Pérez Lasheras, «Arte de ingenio y Agudeza y arte de ingenio», en Aurora Egido y María del Carmen Marín Pina (coords.), Baltasar Gracián: Estado de la cuestión y nuevas perspectivas, Zaragoza, Gobierno de Aragón, 2001, págs. 71-88, pág. 78. Esta investigación había sido precedida por Antonio PéREZ Lasheras, Fustigat mores. Hacia el concepto de la sátira en el siglo XVII, Zaragoza, Universidad, 1994.

22 Eustaquio SÁnchez SALOR, «La poética de la agudeza literaria», en Jesús LuQue-María Dolores Rincón-Isabel Velázquez (eds.), Dulces Camenae Poética y poesía latinas, Jaén-Granada, Sociedad de Estudios Clásicos, 2010, págs. 715-726, en pág. 720 comentaba a Gracián resaltando sus fuentes clásicas: «No hay nada más que hacer un breve recorrido por los distintos tipos de agudeza de ingenio que recoge Gracián para comprobar que en todas ellas opera una figura de pensamiento, o algún recurso basado en el contenido, en las ideas y nunca en la forma». En efecto, Gracián y esta clase de composiciones de la literatura española tienen la característica común de la brevedad, pero concentran un pensamiento muy diverso, favoreciendo una interpretación irónica más que marcando las figuras de expresión».

${ }_{23}$ La línea de desarrollo de esta tradición nos conduce a los orígenes del humanismo, a Boccaccio, como reconocía Antonio José DE VICENTE-YAGÜE JARA, en su estudio sobre la novela satírica del XVIII del caballero Boufflers, «La búsqueda de la felicidad en el s. XviI: Aline, reine de Golconde, cuento libertino de Boufflers», en Àngels SANTA y Cristina Solé CaSTElls (eds.) Texto y sociedad en las letras francesas y francófonas, Lleida, Departament, 2009, págs. 174-185, en pág. 181. 
exceso de la hipérbole o del énfasis, que bordeaban la ironía. Podía adoptar una forma dialogada mediante la reescritura eufemística con paráfrasis de algo dicho. El ingenio manipulaba la actitud de los interlocutores ante una incidencia o inoportunidad con que uno interpelaba a otro, así como la reprensión moral de un vicio o defecto, de manera tácita o disimulada.

Desde el punto de vista lógico, cabía obtener la comicidad de la conjunción de afirmaciones contradictorias o que resultan absurdas en el contexto, o la vuelta del sentido de lo que el interlocutor dice. De manera semejante, se recurría a la conjunción absurda de cosas que se repelen o no son adecuadas. Sin embargo, estas anécdotas podían articularse con un propósito, no solo de confundir la lógica, sino también con un cambio en el ritmo de dicción, al mencionar disimuladamente algo como si fuera falso, aunque fuera verdad. Todo esto apuntalaba el antiguo edificio de la sátira romana a los ojos de las nuevas generaciones.

Todavía al final del XVII, un editor aprovechó el prestigio que conservaba la memoria de Daniel Georg Morhof para publicar bajo su nombre una obra que tituló Commentatio de disciplina argutiarum, en cuyo prólogo hacía una valoración crítica de la influencia que había tenido en la literatura la forma de las $\operatorname{argucias}^{24}$ :

Sunt qui existimant, ad corrumpendam bonae dictionis indolem arguti styli affectationem primum esse inter doctos viros ortam; ac sane negari nequit, adeo intemperantem fuisse argutiarum usum, uti olim post tempora Ciceronis, ita et nostro saeculo post literarum palingenesiam, apud Italos, qui hanc argute scribendi rationem / ita frequentarunt, ut nihil pene ab illis scriberetur, quod non esset argutiis omni ex parte incrustatum. Quod cum fieri viderent passim viri docti et pro mascula et succiplena eloquentia subornari lenoninam aliquam, meretriciam et fucatam, vehementer adversus illud corruptum dicendi genus declamarunt; nec immerito.

Pero en todo caso, en la obra atribuida a Morhof (de 1693) se enfatizaban las normas de estilo más unánimemente defendidas en su tiempo y en el siglo posterior: brevitas, perspicuitas, decorum, urbanitas/rusticitas y una distinción

24 (Pseud.) Daniel Georg Morhof, Commentatio de disciplina argutiarum, s. n., s. l., 1693, págs. 1-2: «Hay quienes piensan que la forma especial de la argucia literaria surgió primeramente entre los eruditos para destruir la esencia del buen estilo; y no se puede negar — hasta tal punto ha llegado el uso de las argucias- que antaño, después de Cicerón, y también en nuestra época, tras de la regeneración en Italia, quienes emplearon asiduamente el estilo de la argucia, / apenas escribieron nada que no quedara invadido de argucias por todas partes. Los eruditos al observar que sucedía que en el lugar de una elocuencia viril y jugosa se había adornado una elocuencia prostituida, a sueldo, y frívola, clamaron contra aquel lenguaje corrompido; y no sin motivo». 
entre la habilidad retórica y la «poetica phantasia» ${ }^{25}$. Estas características se exigían a la composición satírica porque los propios autores de la sátira romana servían de modelo al uso del neolatín, que era la referencia de la preceptiva literaria y del aprendizaje de la lengua. Además, la reflexión sobre la lengua de la sátira en lengua vernácula del XVII estaba influyendo en la valoración de las composiciones antiguas para la historia literaria.

A su vez, la obra de Emanuel Thesauro ${ }^{26}$, reeditada en Alemania, proporcionaba los recursos poéticos para las composiciones breves e ingeniosas, a partir de los lugares retóricos, las categorías filosóficas y lo que él llama «categorías patéticas», tanto en sentencias, como en prosa, en diálogo al modo de Horacio y Persio, dejando a un lado inscripciones y epigramas. La lista de los textos que presentaba esta publicación no se limitaba a los epigramas, ni tampoco a los emblemas o las empresas, sino que comprendía: metáforas, traslaciones de sentido, aliteraciones inusitadas, anagramas, calificativos metafóricos, definiciones metafóricas, apelativos de la jerga militar, proposiciones figuradas, proverbios, reticencias, sentencias, apotegmas lacónicos, synthemata como los de Pitágoras, proposiciones equívocas, oráculos ficticios, alegorías, apólogos, enigmas, dilemas y entimemas lógicos y pantomimas. El método para construir estas formas breves y las sátiras en neolatín o en vernáculo era una inventio que comenzaba por centrarse en la persona o en la acción a la que se dedicaba la composición. Al avanzar en el comentario, distinguía entre sátira, argucia y ridículo, cuidándose mucho de rechazar la obscenidad, e incluso previniendo el eufemismo.

En este contexto literario, la popularidad de Juvenal crecía en admiradores. Secundaban la admiración que habían mostrado Petrarca, Lutero, Calvino y Montaigne ${ }^{27}$. Por su aire desenfadado, se podía imitar cuando se deseaba participar en los debates y críticas literarias o de costumbres. En cambio, hay que

25 (Pseud.) Daniel Georg Morнof, Commentatio de disciplina argutiarum, s. l., Böckmann, 1693. Entre las págs 25-40 se recomienda asiduamente el seguimiento de la retórica y de la poética aristotélicas, tiene muy en cuenta el Pseudo-Longino (pág. 25).

26 Emanuele Thesauro, Idea argutae et ingeniosae dictionis principiis Aristotelicis, Francofurti et Lipsiae, Joannis Melchioris Süstermanni, 1698. En el prólogo de esta edición, donde la pluma de Melchor SüsTERMANN presentaba esta adaptación a sus lectores, se relacionaba la teoría sobre los principales géneros literarios y se proponía alcanzar la medida razonable de la agudeza (pág. 2): «Multa legi scripta oratoria, multa epica, multa lyrica, multa comica, multas inscriptiones antiquas et novas ejusmodi floribus eleganter exornatas, sed illi ipsi autores qui scribere argute sciebant, quae sit ratio argute dicendi ignorabant». ("He leído muchos ejercicios oratorios, muchas obras épicas, muchas composiciones líricas, muchas comedias, muchas inscripciones antiguas y nuevas elegantemente decoradas con flores de ese estilo, pero los autores mismos que empleaban la argucia, ignoraban cuál era la razón del discurso caracterizado por la argucia»). La Idea argutae et ingeniosae dictionis (1698 y 1714) fue uno de los tratados que mayor eco tuvieron en Alemania.

27 Michael von Albrecht, Historia de la literatura romana, Barcelona, Herder, 2 vols., 1997-99, págs. 933-949. 
observar que la obra de Persio, muy alabada en su tiempo por Marcial $(4,29,7)$ y Quintiliano (inst. 10, 1,94), a finales del s. XVII resultaba complicada y oscura. A contracorriente, François de La Rochefoucauld (Réflexions, sentences et maximes morales) destacó sobre todos los poetas de su época y mantuvo en Francia el regusto amargo de su carácter irónico (que contrastaba con el epicureísmo de Charles de Saint-Évremond ${ }^{28}$ ) y por la provocación con el modelo de Petronio en su crítica a jesuitas y jansenistas.

\section{La literatura satírica romana, soporte de la ironía en el siglo XVIII}

Las composiciones breves y con humor abundaban y atrajeron la atención de algunos poetas como John Dryden, que teorizó sobre las causas de la extensión de esta clase de literatura en su Discourse Concerning the Original and Progress of Satire (1693) que influyó en la Europa del XVIII. Francisco Uzcanga Meinecke también recordaba la rehabilitación ilustrada de la invectiva, desgastada por las disputas dinásticas y religiosas ${ }^{29}$. La invectiva aprovechaba el discurso irónico, muy concentrado en la forma poética del epigrama. Esa diversión del ejercicio poético de la lírica se aceptaba como recurso didáctico y como resorte dialéctico. Así se comprueba en la supervivencia de ciertas formas breves que se habían instalado en el transcurso del xVII: inscripciones, epitafios, fábulas y epigramas. Nicolás Boileau asumió la buena opinión que de los autores romanos conocía. La comicidad se combinó con la crítica, mientras que decaían algunas formas literarias al tratar de adaptarse a las exigencias de una convivencia social que cambiaba.

Edward V. Coughling recogía los principales comentarios de los eruditos neoclásicos españoles subrayando sobre todo la continuidad de la sátira sobre

${ }^{28}$ Un contraste sugerido por Jean-Charles DARmon, «Entre épicureisme moral et jugement esthétique: les variations critiques de Saint-Evremond sur l'expression des passions au théâtre», Dix-huitième siècle 35 (2003), págs. 113-140, pág. 119: «La parole heureuse est par essence divertissante: mais en parlant bien d'autre chose, elle permet à l'ego de produire une image éclairante sur lui-même et de miesux revenir à soi».

29 Francisco Uzcanga Meinecke, Sátira en la Ilustración española. Análisis de la publicación periódica El Censor (1781-1787), Frankfurt am Main, Vervuert, 2004, págs. 10-11: «El origen de esta nueva dimensión que alcanza la sátira hay que buscarlo en el entorno de las discusiones que se fraguan en las revistas moralizadoras inglesas de principios del xvIII. Son los editores de The Spectator y de The Tatler, Joseph AdDison y Richard StEele, quienes, inspirados en Dryden y Bolleau, se empeñaron primero en rehabilitar un género que, debido al abuso con que estaba siendo utilizado en intrigas cortesanas y disputas religiosas, había terminado por desacreditarse y poco se diferenciaba ya de la invectiva o del escarnio. / Crean para ello el concepto de true satire, caracterizado por la racionalidad de la argumentación, la moderación en el tono y la despersonificación del objetivo satírico, y lo contraponen a la false satire que nace de la pasión irracional, y, en tono cruel e injurioso, persigue ante todo el escarnio del enemigo $[\ldots]$ ". 
los presupuestos estéticos anteriores. Justifica esta tendencia por la utilidad que presentaba este género, incluso para los partidarios de la renovación cultural del país ${ }^{30}$.

Ignacio de Luzán, en su Retórica de las conversaciones, había tenido muy en cuenta esta literatura languideciente de la agudeza ${ }^{31}$. Coincide con las indicaciones del siglo anterior sobre la clase de lenguaje que debía guardar una virtud de urbanitas, recomendada por los antiguos gramáticos y preceptores. De hecho, la historia literaria reconocía esta característica del uso latino de Marcial a propósito de epigramas que ofrecían un retrato de la Roma de su época ${ }^{32}$. Por eso Luzán, apoyándose en Quintiliano, definía la posibilidad de provocar la risa en la conversación ${ }^{33}$ :

Fingiéndonos ignorantes y lerdos, y diciendo advertidamente por simulación lo que, dicho con seriedad por descuido o ignorancia, sería tontería y disparate, causaremos alegría y risa; la cual procede, en el ánimo del que oye, de aquel gusto con que descubre nuestra ficción y advierte la imitación bien hecha de un hombre rudo y lerdo.

30 Edward V. Coughuing, La sátira, págs. XI-XII defendía la existencia de sátira en las formas (en distintas lenguas europeas) de lírica, épica, narrativa y drama. Reconocía implícitamente un uso alegórico al situar la fábula de IriarTe al comienzo de su capítulo «La poesía satírica» (esp. págs. 25-32). En cambio, la poesía de MELÉndez VALDÉs «La despedida del anciano» (págs. 33-37) correspondía a las expectativas creadas por el antiguo género romano, y todavía más la «Lección poética: Sátira contra los vicios introducidos en la poesía castellana» de Leandro Fernández de Moratín (págs. 43-48). Anotaba también que en las obras de Juan Pablo Forner, la tradición de las formas literarias «ha evolucionado a partir de los modelos antiguos desde la recepción humanista de Luciano, Petronio y Apuleyo, a través de Cervantes, Mayans y VILLEGas» (pág. 70).

31 Ignacio de LuZán, Arte de hablar, o sea, retórica de las conversaciones. Se añaden los Avisos de Isócrates a Demónico, traducidos del griego, ed. de Manuel Béjar Hurtado, Madrid, Gredos, 1991. En la pág. 159 n. a se indica que el capítulo 2.20 de la Poética en la sección «Del estilo jocoso» reproduce casi íntegramente el texto del capítulo XVIII titulado «De los sentimientos ridículos y de las gracias y agudezas jocosas» de este manuscrito editado por Béjar.

32 Eugène NAGEOTTE, Histoire de la littérature latine depuis ses origines jusqu'au VIe siècle de notre ére, Paris, Garnier frères, 3ème édition revue et corrigée, 1887, pág. 426: «Ce sont moins des épigrammes proprement dites que de petits tableaux où il peignait la vie de Rome au jour le jour. [...] pág. 427 Sa langue est classique encore, sinon son goût, qui se ressent de l'époque. Martial abuse de l'antithèse; Il en a tiré de jolis effets, mais quand en lit de suite un certain nombre de ses épigrammes, le procédé se laisse apercevoir: on prévoit ce qui va sortir du gaufrier. [...] Tournoures, expressions, pensées, traits d'esprit, motifs même, tout rapelle et souvent le poète des Amours et de l'Art d'aimer. [...] Un ouvrage dont le tiers est bon est un bon ouvrage. Il s'est prédit sa place dans l'histoire des lettres latines: il se mettait au-dessous de Catulle, mais de lui seulement. C'est qu'en effet tout l'esprit du monde ne vaut pas en art un simple cri du coeur, et ce cri que plus d'une fois fit entendre Catulle, Martial ne l'a jamais eu».

33 Ignacio de Luzán, Arte de hablar, pág. 161. 
Sin embargo, reconocía que la posibilidad de esta variedad agradable en el coloquio no permitía dar continuidad al estilo de Baltasar Gracián ${ }^{34}$. Con todo, admitía un uso moderado de estas habilidades oratorias ${ }^{35}$ :

Digo que muy bien podrá el discreto servirse en su conversación de tales ornatos — de equívocos, de juegos de vocablo, de conceptos y agudezas — para deleitar y mover a risa y herir con donaire, como los use con la debida moderación, observando las circunstancias del tiempo y del lugar y guardándose de la afectación y de la frialdad, que son los vicios en que corre peligro de caer por el uso de tales adornos. Una agudeza se dice afectada cuando es demasiado el trabajo y el artificio con que se manifiesta, y por otra parte es inútil y vana la cognición que de ella resulta.

Sin duda, la literatura en lengua vernácula era la base de la experiencia de los críticos, aunque eligieran la lengua latina para su mejor difusión. En este contexto, la literatura española experimentó también en el estilo de la prosa un desarrollo desde el ensayo hacia formas breves ${ }^{36}$. En la poesía española no faltó el cultivo de la sátira entre los poemas de Alonso de Verdugo y Castilla, conde de Torrepalma y José Antonio Porcel, en la Academia del Trípode y la del Buen Gusto, y entre aquellos otros que vivieron la llegada de las corrientes literarias ilustradas (Gabriel Álvarez de Toledo, León y Mansilla, y Eugenio Gerardo Lobo) ${ }^{37}$. De este modo, Luzán se hacía eco de la preferencia de algunos escritores como reflejo de una forma de entender la vida ${ }^{38}$ :

Gran parte de la belleza del estilo gracioso consiste también en la elección de expresiones ya de sí ridículas, y de modos de hablar bajos y burlescos. Y de estos

34 Ignacio de LuZán, Arte de hablar, págs. 164-165: «Y acerca de esto confieso que no me atrevo a defender el estilo de Gracián, en el cual se dejó llevar por la corriente de aquel siglo y de su genio. Concederé también que aquel tratado de la Agudeza y arte de ingenio se podía haber escrito quizá de otra manera. Diré otrosí (declarando con / sinceridad mis sentimientos) que yo por mí más estimo cuatro versos de Virgilio que todos los conceptos y agudezas de Marcial; y un soneto de Garcilaso u de Lupercio Leonardo, que todos los equívocos y las paronomasias y los conceptos de Góngora, de Lope de Vega u de otros poetas; y que una belleza natural y sencilla me agrada más que otra llena de artificio y afeite».

35 Ignacio de LuZán, Arte de hablar, pág. 167.

36 María Dolores Albiac Blanco, Historia de la literatura española. 4. Razón y sentimiento 1692-1800, Barcelona, Crítica, 2011, págs. 360-361.

37 María Dolores Albiac Blanco, Historia, pág. 459. En este contexto, Álvarez de Toledo escribió un poema «A Roma destruida» celebrando su caída de manera irónica, y en algunos pasajes, sarcástica (María Dolores Albiac Blanco, Historia, pág. 462). El mismo autor escribió la Burromaquia donde contrastan el Archiburro con el Jumentorbo y recuerda, por una parte, la Batracomiomaquia, pero también, algunos efectos irónicos fundados en la denominación que reciben los personajes recuerdan los empleados por Cicerón en los discursos contra Verres.

38 Ignacio de LuZán, Arte de hablar, pág. 172. 
modos tenemos gran copia los españoles; que, en este género de estilo, hablando sin pasión, paréceme que llevamos ventaja a las demás naciones.

Es curioso que Luzán no declare la conexión, que se observa en los ejemplos que escoge, entre este estilo gracioso y el burlesque francés, criticado por Vavasseur. Aunque se produjo una renovación de la poesía castellana, el estímulo principal fueron las modas ${ }^{39}$ de los poetas franceses seguidores de la tradición clásica del siglo XVII. Nicolás Boileau había participado con sus Sátiras en esta cultura de lo burlesco a través de la lectura de Juvenal, Horacio y en rivalidad con Régnier ${ }^{40}$. Le Lutrin es también una muestra del cultivo de la literatura paródica.

El transmisor y comentarista del Arte horaciana supo destacar la singularidad de las anécdotas divertidas y curiosas. Esta estima por el criterio estético de Horacio fue matizándose, y Eugène Nageotte en la conformación del género satírico valoraba también la independencia de Horacio respecto del poder político. Esta cualidad resaltaba en una época en que la relación con los poderosos que protegían la literatura sostenía el ejercicio poético del estilo neoclásico en las distintas naciones ${ }^{41}$.

Por la resonancia que alcanzaba la representación en los teatros y la declamación en privado, la forma cultivada por Horacio configuraba el ideal de la sátira. Aunque, como hemos dicho más arriba, el drama satírico griego tenía poca relación con la sátira del XVII, el prestigio creciente del teatro y el reconocimiento del respetuoso lugar que merecía la comedia latina en el desarrollo del latín literario favorecieron las chanzas en el teatro clásico español y en el francés. En el género burlesco del teatro, cobró gran incremento el entremés y la caracterización de los personajes secundarios del sainete.

39 María Dolores Albiac Blanco, Historia, pág. 469.

40 Joseph Pineau, «L'univers satirique de Boileau: l'ardeur, la grâce et la loi», Paris, Droz, 1990, pág. 66.

${ }^{41}$ Eugène NAGEOTTE, Histoire de la littérature latine, págs. 357-358 (sobre Horacio): «Il a loué Mécène sans doute, et même en termes très vifs. Mais il ne l'a jamais loué de talents qu'il ne possédait pas. Mécène avait la manie des petits vers: c'était bien là pour un flatteur l'endroit sensible, et pourtant Horace ne lui en a jamais fait compliment. Cela fait à la fois l'éloge du poète et de son protecteur: Richelieu ne l'eût pas pris ainsi. [...]। Par toutes ces relations mondaines et autres, par l'esprit et la dignité qu'il y portait, Horace fut un des hommes qui surent le mieux assurer à la poésie, aux lettres, leur rang dans le monde. Il y a quelque ressemblance à ce point de vue entre son rôle et celui de Boileau, avec plus de finesse peut-être, plus de souplesse de la part du Latin, plus de tenue morale de la part du Français. Mais ce sont bien eux qui créant un nouveau genre de noblesse, firent marcher de pair avec les grands seigneurs de la naissance les grands seigneurs de l'esprit". Y también en pág. 361: «Ce ne sont pas comme dans Boileau, de grandes batailles rangées; il n'a pas ce vaste déploiement de rhétorique et d'argument que le satirique français met en ligne à la sueur de son front contre le vice qu'il veut exterminer. Ce système n'est bon que pour un contemporain de Bourdaloue. Horace y va d'une main plus légère: sans battre la campagne, il n'a pourtant pas le plan bien arrêté: c'est le hasard qui le mène, mais le hasard comme il n'existe que pour les têtes bien faites et les esprits naturellement bien ordonnés». 
Por otro lado, al comienzo de la Ilustración plena española, la perspectiva histórica sobre las letras de la Antigüedad contribuía a respetar la continuidad en la enseñanza ${ }^{42}$. Siguiendo a los libertinos, cuyas figuras más destacadas eran Claude-Adrien Helvetius ${ }^{43}$ y Paul-Henri D'Holbach, algunos nobles españoles suscitaron críticas, como la de Jovellanos «A Arnesto» y «Sobre la mala educación de la nobleza». Su texto es una reacción contra la expansión de las costumbres libertinas ${ }^{44}$. Por su parte, Cadalso supo imitar a Marcial, aunque compuso poemas a partir de la lectura de Ovidio, Virgilio, Boscán y Garcilaso, tomando ejemplo del satírico Quevedo, con el que había contado el salmantino Diego Torres Villarroel ${ }^{45}$.

Desde las atrevidas observaciones de Etienne de Condillac ${ }^{46}$ en su Essai sur les connaissances humaines y Traité des sensations, la ética sentimental se extendió juntamente con la filosofía epicúrea, con el olvido del neoestoicismo humanista, en obras como el Arte de gozar de Julien Offray de La Mettrie y su Antiséneca o Discursos sobre la felicidad. Jean-François de Saint-Lambert desarrolló la explicación de ese objetivo, y en su Cathécisme universel de 1797 se fundaba la aspiración a la felicidad en un sentimentalismo que se decantaría fácilmente en la novela.

Entre tanto, el juicio más claro sobre la sátira romana antigua reflejaba la maestría con que se había extendido en las lenguas vernáculas. Lo expresa muy bien Giovanantonio Volpi en su monografía sobre este género, escrita en latín. Su definición del género satírico revela también ese interés por la emotividad que surge de las frustraciones de esa aspiración constante hacia la felicidad («odium in scelera et sceleratos, indignationem ob aerumnas bonorum, et felicitatem improborum, postremo risum, ut remedium paretur tristibus affectibus $\left.{ }^{47} \gg\right)$.

42 Francisco García Jurado, Catálogo razonado de manuales hispanos, págs. 30-31 indicaba la discontinuidad que se produjo entre 1808 y 1833, tras la cual, se introdujeron las ideas románticas. Esta fractura afectó también a la orientación de los comentarios y juicios críticos sobre la literatura latina.

43 Carmen Verde Diego, El pensamiento de Claude-Adrien Helvétius: entre la Ilustración y el liberalismo, Santiago de Compostela, Universidad, 1998 nos muestra una contextualización de la figura de Helvétius, apoyo de algunas de las formas de vivir promovidas por algunos de los ilustrados.

44 Edward V. Coughling, La sátira, págs. 38-43.

45 Visiones y visitas de Diego Torres Villarroel es un claro ejemplo de imitación de Luciano, una fuente distinta de la sátira al estilo de Roma, de manera indirecta, a través de la obra de Quevedo. Por eso indica Edward V. Coughuing, La sátira, pág. 70. que «su desenfrenada imaginación patente en las caracterizaciones grotescas hace predominar los valores estéticos sobre los morales en esta sátira». El título del capítulo «Ensayo satírico» muestra a las claras la influencia de la evolución filosófica sobre el modelo de la sátira moral antigua.

46 Ismael MarTínez-LiéBAnA, «Condillac: conocimiento y mundo externo», Endoxa 11 (1999), págs. 297-320, especialmente en págs. 301-302.

${ }_{47}$ Joannis Antonii VULPII Liber de satyrae latinae natura et ratione, eiusque Scriptoribus qui supersunt Horatio, Persio, Juvenale, Patavii, excudebat Josephus Cominus, 1744, p. 160: «Odio al delito y a los delin- 
Desde su conocimiento de la literatura europea de la época, se remontaba en los siglos hasta los comienzos del Imperio de Augusto para comentar detalladamente y comparar las características de estilo de cada uno de los autores ${ }^{48}$. Los elogios a Horacio ${ }^{49}$ secundaban la opinión general de su época, pero mayor interés tenía en describir el uso literario de la lengua de Roma por los autores imperiales. Dedicaba particular atención al estilo de Juvenal, que comparaba con el de Horacio en cuanto al uso de figuras. En cambio, la contención de Persio, consecuentemente, le parecía fría y severa ${ }^{50}$. El atrevimiento juvenil de la sátira de Persio distaba mucho de la alabanza que recibía Horacio de los estudiosos de la literatura ${ }^{51}$. Por eso, el juicio pronunciado por Eugène Nageotte ( «t pourtant, à vrai dire, Perse n'est pas un grand poète ${ }^{52}$ ) reconocía la deuda de la crítica precedente con la opinión establecida por Joseph Justus Scaliger, que había seguido los comentarios de Isaac Casaubon a la obra de Persio ${ }^{53}$. De

cuentes, indignación por las penas de la buena gente, y por la felicidad de los malvados; al final, la risa, para remediar las tristezas».

48 Esta valoración del cuidado en el estilo como característica distintiva de la obra de Persio, que continuaba la estima de los críticos antiguos fue subrayada en la revisión de Wilhelm KroLl del manual de literatura escrito por W. S. TEuffEL, Teuffels Geschichte der Römischen Literatur, sechste Auflage, unter Mitwirkung von Erich Klostermann-Rudolf Leonhard und Paul Wessner, neu bearbeitet von Wilhelm Kroll und Franz Skutsch, dritter Band, die Literatur von 96 nach Chr. bis zum Ausgange des Altertums, Leipzig. Teubner, 1913, p. 3: «Sein ernster und kraftvoller Geist hat weniger künstlerischen Aufbau im Auge als die Sache; unbekümmert um formelle Unebenheiten (Wiederholungen, Nachträge u. Dgl.) legt er das Hauptgewicht auf die Schilderung und Ausgestaltung des Einzelnen, worin er sich kaum genug tun kann. Daher auch die rhetorisch gesteigerte, beziehungsreiche Sprache, welche dem vollen Verständnis grosse Schwierigkeiten bereitet».

49 Joannis Antonii VulPI, Liber de satyrae, pág. 140: «In Satyris suis excellit pura Latinitate, gratia narrationum, suavibus apologis, apheleia seu simplicitate, incredibili lepore atque urbanitate» («Destaca en sus Sátiras por una latinidad pura, por el encanto de sus narraciones, por sus delicados apólogos, por apheleia [tersura] o sencillez, por un atractivo y una elegancia increíbles»).

50 Joannis Antonii VulPI, Liber de satyrae, págs. 141 y 143: «Celerem atque expeditum in scribendo se praestat: verborum parsimoniam soliditate sententiarum et quasi graviditate compensat: excellit gorgotes, nempe truculento et severo stylo [...]. I Apud Persium ioco figurarum est insignis ethopoeia et enargeia, morum alienorum imitatio et evidentia [...]. Nihilominus in Satyris huius poetae verborum tropi, catachresis praecipue, frequentissime occurrunt: quae non exigua sane obscuritatis causa est» («Se muestra ágil y desenvuelto al escribir, compensa la sobriedad en el ahorro de palabras con la solidez de sus pensamientos y con una cierta severidad: resalta su gorgotes [fiereza], pues con su estilo mordaz y severo [...]. / En Persio con el juego de las figuras hay una etopeya señera y una enargeia [evidencia], la imitación de las actitudes de otros y su denuncia [...]. Sin embargo, en las Sátiras de este poeta los tropos y sobre todo, las catachresis [extensión abusiva del sentido] aparecen con muchísima frecuencia: esto sí que es un motivo no insignificante de oscuridad»). Para René Pichon, uno de los autores que mantenía la tradición de la crítica del XVIII, Histoire, pág. 550 «Perse est un pur stö̈cien».

51 Eugène NageotTe, Histoire de la littérature latine, pág. 416: «Pour lui le mal n'est plus comme aux yeux d'Horace une sottise dont on doit rire, mais un crime qu'il faut exterminer, et il pousse sa charge, frappant comme un sourd, ainsi que Madame de Sévigné devait le dire Bourdaloue».

52 Eugène NaGEOTTE, Histoire de la littérature latine, pág. 416.

53 Eugène NAGEOTTE, Histoire de la littérature latine, en nota a la pág. 417: «Jos. Scaliger, qui le tance d'importance pour son obscurité, ne lui reconnaît d'autre mérite que de susciter d'admirables travaux de critique: 
hecho, la actitud estoica hacia los defectos en el comportamiento social, más marcada en la obra de Persio, pero persistente en Juvenal, resultaba molesta en opinión de Eugène Nageotte, que celebraba la habilidad de Horacio para conseguir la complicidad del lector u oyente, aunque su mensaje y el de los clásicos imperiales fuera esencialmente el mismo ${ }^{54}$. La historia literaria relacionó la actitud de Juvenal hacia el endurecimiento del control político en Roma con la capacidad de expresión que el autor muestra en sus composiciones, gracias a la habilidad retórica ${ }^{55}$.

El primer director de la Real Academia de la Historia, Agustín de Montiano y Luyando, resumía la historia de la sátira romana antigua ${ }^{56}$. En sus Notas para el uso de la Sátira recogía ya la conclusión de los anteriores tanteos sobre los autores que participaban de ese género, determinando la coherencia entre sus obras y facilitando la comprensión de su variedad ${ }^{57}$.

Non pulchra habet, sed in eum pulcherrima possumus scribere» («No tiene versos hermosos, pero contra él podemos escribir los más hermosos»). Il songeait sans doute au Perse de Casaubon oû la saulce vaut mieux que le poisson».

54 Eugène NAGEOTTE, Histoire de la littérature latine, pág. 362: «On se lasse bien vite des éclats de voix de Juvénal et de cet état de colère fiévreuse dans lequel il vous met tout d'abord et vous tient jusq'au bout: cela échauffe le sang, le rafraîchit [...]. Horace n'est pas un maître, encore moins un pédant de vertu: il y a même parfois dans sa morale de terribles accrocs. Mais comme il ne cherche point à les cacher, on les lui pardonne, on en rit avec lui. On aime encore mieux cela qu'un stoücisme qui nous écraserait de son impeccabilité».

55 Resulta curiosa la opinión de NAGEOTTE cuando afirmaba que la mitología era una materia «inocente» respecto del poder (no parecía haber leído a Thomas Hobbes ni a Francis BAcon en su De veterum sapientia) y el reflejo del desprestigio de la retórica en su tiempo: Eugène NAGEOTTE, Histoire de la littérature latine, pág. 419 y 421-422 (sobre Juvenal): «Depuis Horace, la satire effarouchée par un despotisme soupçonneux, n'avait osé se produire en plein jour. On se réfugiait dans la mythologie, matière innocente. [...] / Il vise à l'effet: élevé dans les cris de l'école, comme dit Boileau, il en a pris l'exagération dans l'expression comme dans la pensée. [...] / On sent ainsi à chaque pas la malheureuse influence de ces exercises déclamatoires auxquelles il s'était livré jusq'à la quarantaine. Il y avait perdu le juste sentiment des choses, et peut-être aussi l'art de composer. Chacune de ses satires est une série de tirades plutôt qu'un ensemble logique. A chaque instant le fil se casse et, comme le style est assez souvent surchargé, que les allusions sont naturellement très nombreuses et fort souvent obscures».

56 Agustín de Montiano y Luyando, «Notas sobre el uso de la sátira», en Memorias literarias de la Real Academia Sevillana de Buenas Letras, tomo II, publicado a expensas de su director D. Francisco del Cerro, págs. 233-247 en págs. 235-236: «Como labró la cuna de la sátira la libertina gentilidad de Roma, no es extraño que se criase en ella un monstruo de tan perniciosas calidades, ni que viniese a nosotros impuro y contrario al cristianismo. / Quintiliano le asegura este orijen $\langle s i c\rangle$; y los que juzgaron que lo era el espectáculo satírico de los Griegos, se equivocaron con la uniformidad del nombre; por haber sido una representación que por lo regular se componía de sátiros; bien que en nada mordaz ni ofensiva. La sátira latina se llamó en sus principios, según los gramáticos, satura, que valía tanto como plato de diversos manjares, o como nosotros decimos, olla podrida. Perdió muy pronto semejante sencillez, y mudó del mismo modo con el condimento el nombre y el gusto».

57 Agustín de Montiano y Luyando, «Notas sobre el uso de la sátira», pág. 236: «Llegó a nosotros por Horacio, Juvenal, Persio, Marcial y otros más antiguos poetas, con las corrompidas señales de su crianza, en gran parte, ya que no en todo, y por esto los más de sus imitadores han caído en los defectos del orijinal $<$ sic $>$. Lo peor ha sido, que como es propensión muy común el ansia de parecer superiores a otros, son muy raros 
Siguiendo esa línea que se consagraba a finales del xvIII y comienzos del XIX, Luis de Mata y Araujo ${ }^{58}$, en su obra sobre retórica y poética, mostraba la conclusión de este proceso de valoración de una crítica satírica respetuosa, como la recomendada por Vavasseur y Luzán. Los modelos que marcaban los límites y características de las composiciones de esta clase olvidaban a Luciano, Petronio, y Marcial ${ }^{59}$. Todavía Remond de Saint-Mard renovó la pauta lucianesca y senecana en Francia, y fue reconocido como renombrado autor satírico por nuestro Francisco Sánchez Barbero ${ }^{60}$. En cambio, Mata y Araujo difiere en la manera de explicar el origen del género, combinando la teoría de la relación con el teatro antiguo, sumándose a la opinión más difundida en su tiempo ${ }^{61}$.

los que no gusten y se complazcan de oír patentes en el mundo de los defectos del prójimo. Esperimentamos $<s i c>$ que Perico y Marica, el Patán de Caravanchel y otros personajes de esta laya, en el siglo presente y en el pasado, divirtieron y ganaron al público, sacando a vergüenza los vicios verdaderos o falsos de los sugetos $<s i c>$ de mayor carácter y digna recomendación, con universal aplauso de sus lectores, que los preferían, y prefieren a las infinitas obras de madurez y prudencia, que solamente se corrijen $<s i c\rangle$ las faltas, sin desdoro de los que las cometen.».

58 Luis de Mata y Araujo, Elementos de Retórica y Poética extractados de los autores de mejor nota, Madrid, Imprenta de José Martín Avellano, 1818, p. 157: «¿Qué es la sátira? Es un poema jocoso, libre y agudo, que sirve para combatir los vicios y malas costumbres, sin dirigirse a personas determinadas, ni directa ni indirectamente. La sátira efectivamente persigue y ridiculiza los vicios; pero no debe señalar las personas que los tienen. <Mart. 10, 33, 9> Parcere personis, dicere de vitiis» («Ser respetuoso con las personas, denunciar los vicios»).

59 Luis de Mata y Araujo, Elementos de Retórica y Poética, pág. 159: «¿A qué autores satíricos podremos consultar como modelos? En latín, a Horacio, Juvenal y Persio; en francés, a BoileAu, y en castellano tenemos muchísimos autores, como que nuestra lengua se presta con más naturalidad que ninguna otra al chiste y a sales picantes. Merecen leerse la de Lupercio de Argensola, escrita contra una dama cortesana, llamada la Marquesilla; algunas de Quevedo; la de Jorge Pitillas; las letrillas satíricas de Góngora, de QueVEDO, de IGLESIAS, y otros».

60 Francisco SÁnchez Barbero, Principios de Retórica y Poética, Madrid, Imprenta de la Administración del Real Arbitrio de Beneficencia, 1805, págs. 271-272: «La Sátira es un poema por el qual se combaten los vicios o los ridículos. Son su objeto las debilidades de los hombres, sus extravagancias, su perversidad, en suma, todos los caracteres odiosos y perjudiciales a la sociedad. Parece que en el corazón del satírico se halla un germen de misantropía y de malignidad, disfrazadas con el velo de la virtud; el placer de desgarrar a un semejante y el deseo de vengarse. Quando así fuere, yo condenaré los escritos maldicientes, y al autor con ellos. Pero alabo y defiendo aquellas sátiras que, siendo un antídoto contra los ridículos, un fuerte cáustico y azote de los vicios nos enseñan máximas sutiles, nos despiertan y / recrean con la viveza y verdad de las pinturas, sin señalar al vicioso. Parcere personis, dicere de viciis. La sátira o persigue los vicios, o los ridículos. Los vicios son aborrecibles y no es posible chancearse con lo que se aborrece. Conviene pues derramar hiel sobre ellos, tronar como el cínico Juvenal lleno de indignación, acosarlos con el estilo que dicta el aborrecimiento, estilo mordaz, acre y vigoroso. Los ridículos no merecen ser aborrecidos formalmente, sino con el menosprecio y risas, con ironías, chanzas y zumbas. La sal, la chispa, las gracias ligeras y el donaire, reflexiones son las armas que convienen a esta clase de sátiras (Remond de SAINT-MARD) Horacio y BoILEAU presentan el modelo».

${ }_{61}$ Luis de Mata y Araujo, Elementos de Retórica y Poética, págs. 157-158: «¿Qué origen tuvo la sátira? Nació entre la embriaguez y disoluciones que se cometían en las fiestas saturnales entre los romanos, y fue invención de estos, como dice Quintiliano <inst. 10, 1, 93> Satira quidem tota nostra est («Ciertamente la sátira es toda nuestra»), libro primero de orat. cap. primero. De tan malos principios, los medios y los fines no podían ser muy buenos. Los satíricos de aquellos tiempos alimentaban el germen de malignidad y venganza 
Francisco Lafarga, en su conocido estudio sobre Voltaire en España, comentaba los juicios de los críticos españoles ${ }^{62}$ sobre el estilo de este autor francés en los diferentes géneros que cultivó. Lo que más interesaba era el teatro volteriano y no las obras satíricas, cuando su humor corrosivo nos resulta tan característico. Ciertamente, las críticas recogidas por Lafarga revelan muy claramente la distinción que alcanzaba Voltaire entre sus contemporáneos en la factura de las formas breves. Observamos entonces el fundamento de los ejercicios escolares que seguramente habrían sido el estímulo de aquel joven para su dedicación a las letras. A pesar de las dudas sobre el origen de la sátira, la temática característica excedía el ejercicio poético como refugio de la cada vez más desprestigiada Retórica ${ }^{63}$.

Los jesuitas (como François Vavasseur) habían abogado por la contención en las burlas y parodias, por lo que una actitud tal resaltaba aún más en un antiguo alumno del Collège Louis-le-Grand. Poco le animaban los temas, tanto poéticos como dramáticos, explotados por otros famosos autores literarios del XVII, a pesar de que procuraba imitarlos para que le permitieran tener parte en los círculos intelectuales. La Henriade ${ }^{64}$ fue al mismo tiempo imitación, adulación, parodia de las obras épicas de los jesuitas y resignado tributo a la cultura nobiliaria impulsada desde la corte. Según Javier del Prado ${ }^{65}$, Voltaire supo «convertir la historia de las gestas y de los héroes en una historia de las costumbres y de la sociedad». En lugar de transformar la poesía y el drama de su tiempo con un sentido nuevo, su habilidad para la narración desplegó una múltiple variedad de registros, desde la burla y la parodia hasta el sarcasmo. La metáfora y el símbolo

\footnotetext{
contra sus semejantes, que no / solo se contentaban con ridiculizar los vicios, sino que señalaban las personas que los tenían. Posteriormente los Toscanos, llamados Histriones, la representaban en los teatros; y este fue el principio de la comedia romana que empeoró cada vez más la sátira con tal desenfreno y mordacidad, que no perdonaba a los ciudadanos de la más alta clase; pero contenidos después los autores satíricos por las leyes, ha quedado la sátira reducida a lo que debe ser, tal como la hemos definido».

${ }^{62}$ Francisco Lafarga, Voltaire en España (1734-1835), Barcelona, Universitat, 1982. En su primer capítulo recoge las opiniones (págs. 17-44).

63 Luis de Mata y Araujo, Elementos de Retórica y Poética, pág. 157: «¿Cuál es la materia de la sátira? Son los defectos ridículos y odiosos, como la pereza, la adulación, la charlatanería, la ambición, la excesiva prodigalidad y como dice Juvenal <IVV. 1, 80-81>, Quidquid agunt homines, votum/ timor, ira, voluptas/ gaudia, discursus, nostri farrago libelli ("Cualquier actividad humana, un deseo, un temor, la ira, el placer, la alegría, lo que se dice, es la cosecha de nuestro librito"). Su estilo debe ser familiar, pero mezclado de gracias y sales, para que las reprensiones se reciban sin desagrado; y las sentencias deberán ser frecuentes, agudas y picantes».

64 Ignacio de Luzán, Memorias literarias de París, en Obras raras y desconocidas, ed. de Guillermo Carnero, Zaragoza, Larumbe-Prensas Universitarias-Instituto de Estudios Turolenses-Gobierno de Aragón, 2009, págs. 97-99. De manera semejante a Voltaire y al Lutrin de Boileau, Alexander Pope escribió una parodia de la épica heroica en The Rape of the Lock.

65 Javier del Prado, Historia de la literatura francesa, Madrid, Cátedra, 1994, pág. 559.
} 
como conceptos abstractos estimulantes de la imaginación en el relato alcanzaron una aplicación muy notable en sus cuentos satíricos. Para su generación, Antoine Furetière, que siguió el modelo de Juvenal como ningún otro, por la necesidad de resistir el juicio de los demás, con un especial vigor en su Couches de l'Académie (1687), había sido una referencia literaria importante. En cambio, Voltaire, tal vez saciado del genio de Furetière (autor de Nouvelle allégorique) se permitió criticar el uso de la alegoría, que consideraba abusivo en la literatura y en la oratoria de su tiempo ${ }^{66}$ :

No puede negarse que sobresale en dichas alegorías una afectación que se opone a la verdadera elocuencia. [...] La elocuencia, que de día en día se corrompió más y no brilló hasta la época que acabamos de indicar, llegó al mayor ridículo / en todos los pueblos bárbaros hasta el siglo de Luis XIV. [...] Los sermones de Italia participaban de este gusto depravado, y los de Alemania eran aún peores.

El desprecio de la oratoria que mostraba Voltaire se puede corroborar con la opinión de Ignacio de Luzán sobre la escasa sustancia filosófica de los discursos parisinos $^{67}$. Los estudios sobre la Antigüedad pasaron a un plano diferente de la realidad cotidiana, en la que, mientras la invectiva sobresalía por encima de los elogios, la ironía colonizaba la prensa, los panfletos y la novela. La reflexión se fundaba entonces en el progreso de la arqueología cultural y dejaba su aliento inspirador a otras voces en la literatura europea. De acuerdo probablemente con la opinión de Voltaire sobre la alegoría, Francisco Sánchez Barbero desconfiaba de la poesía de Villegas ${ }^{68}$.

Por su parte, Pablo de Olavide recogió las obras volterianas en su biblioteca, y mostraba un particular aprecio por Candide entre la serie de las obras

${ }^{66}$ Voltaire, Diccionario filosófico, (ed. Ana Martínez Arancón), Madrid, Temas de hoy, 1995, págs. $71-72$.

67 Ignacio de Luzán, Memorias, pág. 160: «De aquí resulta que, ordinariamente, en las obras que salen hoy día en París se hallará una falta de método y de solidez en los discursos, en los cuales solo ha trabajado la imaginación viva del autor. Los sofismas, los paralogismos, las divisiones imperfectas son frecuentes. Un ingenio agudo y ayudado con algunas especies leídas abraza con facilidad un pensamiento nuevo y a medio digerir le aborta, le adorna y le traslada al papel y a la imprenta».

${ }^{68}$ Francisco Sánchez Barbero, Principios de Retórica y Poética, pág. 272: «Tiemblo nombrar a Villegas porque sus poesías, a excepción de alguna otra rarísima composición, están escritas con poco gusto y con sobrada arrogancia». Este detalle relacionaba la sátira con las composiciones poéticas breves de la poesía anacreóntica, en la temática del banquete, muy popular en el humanismo. En cambio, al mencionar los autores que sirven de modelo para el género de la sátira, que coinciden con los citados por Mata y Araujo, elogia la obra consagrada por los críticos de su tiempo: "Don Melitón Fernández", que llevó el accésit de la Real Academia Española; dos impresas en el Censor; la primera empieza así: "Déxame, Arnesto, déxame que llore". La segunda: "Ves, Arnesto, aquel majo en siete varas"». 
narrativas ${ }^{69}$. En cambio, Juan Andrés se resistía a admitir de VolTAIRE este cuento burlesco ${ }^{70}$. Una habilidad semejante para aplicar las formas obtenidas de las lecturas se puede suponer en la literatura de un autodidacta como Rousseau, que escogió una frase de Juvenal («vitam impendere vero» 4, 91) como divisa. Esta llamada a la cordura en la vida pública no quebraba la línea de evolución de las aspiraciones sociales hacia la consecución de nuevas metas de prosperidad y bienestar. René Pichon reconocería después el atractivo de la obra satírica de Juvenal como vuelta a los orígenes de Lucilio ${ }^{71}$. Pero como crítico e historiógrafo de la literatura latina, mostró la clara preferencia del gusto de la época por Horacio y su manera de cultivar el género satírico ${ }^{72}$.

Por el lado poético, en Italia, entre los principales autores neoclásicos (hasta Leopardi), Aurelio de'Giorgi Bertòla compuso algún epigrama con acento satírico, que también tenía afinidad con la canción popular veneciana de Anton Maria Lamberti. Tuvo un gran eco la actividad literaria y periodística con tono de humor de Giuseppe Parini (Il giorno) que, de manera semejante en España, se canalizó por medio de la publicación El Censor. Así se favoreció el mantenimiento de los recursos propios de la sátira antigua en una forma de crítica de enorme influencia a través de la prensa escrita ${ }^{73}$.

En Alemania, Johann Christoff Gottsched escribió su Versuch einer critischen Dichtkunst vor die Deutschen (1730) recordando la historia de la literatura latina como fundamento de la literatura alemana. Seguía la interpretación de Boileau del Arte horaciana, y tenía muy clara la importancia de la sátira latina, cuyos autores citaba, y comentaba como ejemplo de buen gusto ${ }^{74}$. Don Quixot

69 Francisco Lafarga, Voltaire, págs. 29-30.

70 Francisco Lafarga, Voltaire, pág. 22. José Manuel LOSADA, «Les utopies dans Candide de Voltaire», en Àngels SANTA y Cristina SolÉ Castells (eds.) Texto y sociedad en las letras francesas y francófonas, Lleida, Departament, 2009, págs. 166-173. A la difusión de estos cuentos se sumó también los Contes moraux de Marmontel, menos variados e ingeniosos que los de su amigo Voltaire.

71 René Pichon, Histoire, pág. 642: «Au fond, l'oeuvre de Juvénal est très complexe, très riche en éléments divers. Elle est faite à la fois de rhétorique et de sincérité, de trivialité et de noblesse, de haines personnelles et de graves inspirations philosophiques [...]. Dans le développement du genre satirique, il revient à la conception de Lucilius, mais avec plus d'âpreté et de violence; il invente ou réinvente une satire-pamphlet, bien plus empoignante que les causeries aimables d'Horace ou les sages leçons de Perse».

72 René Pichon, Histoire, págs. 555-556: «Les défauts apparaissent surtout lorsque l'on compare Perse à Horace. Que sont devenus ce ton discret, cette politesse exquise des charmants billets adressés par Horace à ses amis, ce sourire à la fois malicieux et indulgent d'un homme qui voit tout et ne se scandalise de rien? [...] / Pour le charme familier, Perse est encore inférieur à Horace. [...] Leur obscurité proverbiale vient sourtout de la concision dans les phrases et de l'absence de transitions dans la suite des idées. [...] Enfin Perse manque de sentiment artistique. Le souci de la grâce, le culte de la forme lui font défaut».

73 Ana Hontanilla, «Disección anatómica de la imaginación y de la moda en el sueño Satírico 54 de El Censor», Revista Hispánica Moderna 62.1 (2009), págs. 57-76.

74 Johann Christoph GотTSCHED, Versuch einer critischen Dichtkunst vor die Deutschen, darinn erstlich die allgemeinen Regeln der Poesie [...], Leipzig, verlegts Bernhard Christoph Breitkopf, 1730, pág. 72 tra- 
todavía se consideraba bajo el aspecto de la sátira, a través de las traducciones y adaptaciones a las distintas lenguas. Pero el reflejo del debate sobre esta producción en lengua alemana se observa en la obra del poeta satírico Gottlieb Wilhelm Rabener, que en su Sendschreiben von der Zulässigkeit der Satyre 1751, elegía la forma del ensayo breve, a la manera epistolar, para explicar su arte y defender la sátira desde sus orígenes ${ }^{75}$.

A través de esta perspectiva es fácil comprender que el espíritu de la sátira romana se trasladó a la narrativa, como la novela cervantina apuntaba. Francisco Uzcanga Meinecke ha estudiado el entorno de El Censor con referencia a las distintas formas de literatura joco-seria ${ }^{76}$. La limitación de la invectiva de la sátira dejaba a la ironía y a la didáctica los únicos rasgos que definían este género literario. Con todo, la sátira se prestaba a la expresión del debate crítico.

\section{Conclusiones}

En las muestras que hemos reunido en estas líneas se observa cómo la sátira latina era una referencia para seleccionar las múltiples manifestaciones poéticas de la risa y el humor de las literaturas europeas. Este orden de la razón fue centrando la singularidad de la poesía satírica latina respecto de la tradición helénica. Así, en la cuestión de los orígenes se había determinado la función de estos poemas en la tradición de la lengua literaria latina, en la que Lucilio había introducido el hexámetro para la sátira, mientras que la imitación menipea había combinado risa, didáctica moralizante y máscara.

Por efecto de la producción creciente de formas literarias satíricas en el XVII, sobre todo en Francia, la estima por la poesía filosófica de Persio cedió con el olvido del neoestoicismo y del racionalismo cartesiano. Tras el universal

tando los orígenes de la poesía alemana afirmaba: «Da nun dergestalt die Poesie sich dann die Thon und Singe Kunst beliebt gemacht hatte, so war es kein Wunder, dass noch immer mehr und mehr unmusicalische Gedichte erfunden wurde. Dahin gehören nun die Satiren Lucilii, Horatii, Juvenalis und Persii». En pág. 114 citaba la sátira horaciana $(1,10)$ como ejemplo de buen gusto.

75 Gottlieb Wilhelm RabenER, Sammlung satyrischen Schriften, Leipzig, im Verlage Johann Gottfried Dycks, Bd. I, págs. 135-146, que en pág. 141 coincide con otros eruditos en fijar los límites de la sátira para no dañar a las personas: «Eine der gemeinsten Regeln ist diese: Die Satyre soll die Laster tadeln, nicht aber die Personen». Un poco más adelante (pág. 144) afirmaba: «Mein Vortrag muss ordentlich seyn; denn ich will andre überzeugen. Er muss nicht mehr Antheil daran haben, als meine Einbildungskraft. Aber dunkel darf er auch nicht seyn; denn ich will den Verstand meiner Leser nicht ermüden, sondern belustigen».

76 Francisco Uzcanga Meinecke en Sátira, pág. 119, comentaba el polimorfismo de la crítica satírica en El Censor como característica de la sátira; [...] que se desarrollaba también en (págs. 142-143) formas de literatura popular que entroncaban con la literatura clásica. Por otra parte, comentaba cómo se deslizaba la ironía en muchas páginas de El Censor y el falso elogio irónico (págs. 162-164). 
asentimiento al equilibrio del ejercicio horaciano de la sátira, se produjo un reconocimiento del arte de Juvenal como restauración de las posibilidades marcadas originalmente por Lucilio.

Con el desarrollo de la nueva ficción en las lenguas vernáculas, la composición breve se restringía a la crítica mordaz, pero respetuosa, además del empleo didáctico. Bajo estas dos adscripciones genéricas, los recursos retóricos empleados en la sátira se aprovechaban en otros géneros, como la epistolografía o el ensayo breve. A medida que se debilitaba la capacidad de inventar argumentos por la deficiente formación filosófica, el discurso en lengua vernácula se volvía más sencillo, en correspondencia también con la línea estilística recomendada, de manera que la ironía y el humor que se habían refinado continuaran sorprendiendo al lector entre líneas. La historiografía literaria latina se nutrió de los comentarios, los diccionarios críticos de autores y los estudios particulares del género recogidos en el s. XVIII, al tiempo que secundaba las conclusiones del debate sobre la sátira y la literatura joco-seria en lengua vernácula. 